\title{
Gene-based microsatellite development for mapping and phylogeny studies in eggplant Anikò Stàgel ${ }^{1}$, Ezio Portis*1, Laura Toppino ${ }^{2}$, Giuseppe Leonardo Rotino ${ }^{2}$ and Sergio Lanteri ${ }^{1}$
}

Address: ${ }^{1}$ Di.Va.P.R.A. Plant Genetics and Breeding, University of Torino, Via L. da Vinci 44, 10095, Grugliasco (Torino), Italy and ${ }^{2}$ CRA-ORL Research Unit for Vegetable Crops, Via Paullese 28, 26836 Montanaso Lombardo, LO, Italy

Email: Anikò Stàgel - aniko.stagel@unito.it; Ezio Portis* - ezio.portis@unito.it; Laura Toppino - laura.toppino@entecra.it; Giuseppe Leonardo Rotino - giuseppeleonardo.rotino@entecra.it; Sergio Lanteri - sergio.lanteri@unito.it

* Corresponding author

Published: 30 July 2008

BMC Genomics 2008, 9:357 doi:10.1/86/147|-2164-9-357
Received: 12 March 2008

Accepted: 30 July 2008

This article is available from: http://www.biomedcentral.com//47/-2/64/9/357

(c) 2008 Stàgel et al; licensee BioMed Central Ltd.

This is an Open Access article distributed under the terms of the Creative Commons Attribution License (http://creativecommons.org/licenses/by/2.0), which permits unrestricted use, distribution, and reproduction in any medium, provided the original work is properly cited.

\begin{abstract}
Background: Eggplant (Solanum melongena L.) is a member of the Solanaceae family. In spite of its widespread cultivation and nutritional and economic importance, its genome has not as yet been extensively investigated. Few analyses have been carried out to determine the genetic diversity of eggplant at the DNA level, and linkage relationships have not been well characterised. As for the other Solanaceae crop species (potato, tomato and pepper), the level of intra-specific polymorphism appears to be rather limited, and so it is important that an effort is made to develop more informative DNA markers to make progress in understanding the genetics of eggplant and to advance its breeding. The aim of the present work was to develop a set of functional microsatellite (SSR) markers, via an in silico analysis of publicly available DNA sequence.
\end{abstract}

Results: From $>3,300$ genic DNA sequences, 50 SSR-containing candidates suitable for primer design were recovered. Of these, 39 were functional, and were then applied to a panel of 44 accessions, of which 38 were cultivated eggplant varieties, and six were from related Solanum species. The usefulness of the SSR assays for diversity analysis and taxonomic discrimination was demonstrated by constructing a phylogeny based on SSR polymorphisms, and by the demonstration that most were also functional when tested with template from tomato, pepper and potato. As a results of BLASTN analyses, several eggplant SSRs were found to have homologous counterparts in the phylogenetically related species, which carry microsatellite motifs in the same position.

Conclusion: The set of eggplant EST-SSR markers was informative for phylogenetic analysis and genetic mapping. Since EST-SSRs lie within expressed sequence, they have the potential to serve as perfect markers for genes determining variation in phenotype. Their high level of transferability to other Solanaceae species can be used to provide anchoring points for the integration of genetic maps across species. 


\section{Background}

The eggplant (Solanum melongena L.), also known as aubergine or brinjal, belongs to the Solanaceae, but unlike most of the solanaceous crop species, it is endemic to the Old, not the New World. Its progenitor is presumed to have been the African species $S$. incanum [1], but its centre of domestication and genetic diversity lies in the IndoBurma region, where it has been grown for at least 1,500 years [2]. Despite its economic and nutritional importance, its genome has been little studied, in contrast to those of the other cultivated solanaceous crops tomato, potato and pepper, in which high density genetic linkage maps have been established [3-6]. The literature contains only a few reports describing RAPD [7], AFLP [8,9] and SSR [10,11] genotyping, a genetic map constructed with AFLP and RAPD markers [12] and a comparative genetic map, based on tomato sequences [13].

Microsatellites (SSRs) are short tandem repeats of simple (1-6 nt) motifs, and their value for genetic analysis lies in their multi-allelism, codominant inheritance, relative abundance, genome coverage and suitability for highthroughput PCR-based platforms [14]. It was long assumed that SSRs were primarily associated with noncoding DNA, but it has now become clear that they are also abundant in the single and low-copy fraction of the genome $[15,16]$. These latter SSRs are commonly referred to as "genic SSRs" or "EST-SSRs" and are present in 1 to $5 \%$ of the expressed plant DNA sequence deposited in public databases. With the increasing volume of publicly available unigene and cDNA sequences emerging from large-scale EST sequencing projects, the conventional need to generate enriched genomic libraries and to perform the necessary sequencing can now be largely bypassed [17]. Genic SSRs tend to be more readily transferable between (related) species or genera than genomic ones, since coding sequence is better conserved than noncoding sequence; however, they do tend to be less informative than conventional SSRs, particularly in the context of related genotypes $[18,19]$. On the other hand, they provide a powerful means to link the genetic maps of related species, and since many of them are located within genes of known or at least putative function, any allelic variation present can be exploited to generate perfect markers [20].

We present here our progress in the development and preliminary characterization of a set of eggplant SSR markers, derived from public database sequence, along with an evaluation of their experimental and in silico transferability among other solanaceous species.

\section{Results and discussion SSR motif frequency and distribution}

At the time surveyed, the Solanaceae Genomics Network database (SGN; http://www.sgn.cornell.edu) contained
3,181 eggplant ESTs, ordered into 1,841 unigenes (617 contigs and 1,224 singlets). An additional 176 sequences were retrieved from the EMBL sequence database http:// www.ebi.ac.uk/embl. The non-redundant sequence pool contained 1,864 sequences representing 743,527 bp of genomic sequence. Within these, 64 contained one or more SSR (70 in total, including 20 mono-, 11 di-, 36 tri, one tetra- and two hexanucleotide motifs). One sequence contained three SSRs, while ten SSRs were of the compound type (SSR containing stretches of two or more different repeats). The mean separation between two SSRs was $\sim 10.6 \mathrm{~kb}$, equivalent to one SSR per 29 sequences. This distance is somewhat greater than that estimated for several monocotyledenous [15,21] and dicotyledenous [22] species, perhaps because of the greater stringency of the criteria and the lesser size of the sequence dataset.

The properties of the 70 SSR loci identified are summarised in Table 1, classified on the basis of repeat motif and the number of repeat units. Trinucleotides were the most frequent $(51.4 \%)$, followed by mono- $(28.6 \%)$ and dinucleotides (15.7\%). Tetra- and hexanucleotides were rare. Although trinucleotide motifs are less frequent in genomic libraries, they represent the most common class in expressed sequence $[18,23,24]$, since variation in repeat number does not normally affect downstream peptide sequence, unlike mono-, di-, or tetra-nucleotide motifs, which generate frameshift mutations and therefore are more likely to be selected against [25]. All ten possible trinucleotide motifs were recovered, with AAG/CTT the most frequent $(30.6 \%)$, as has been seen in other Solanaceae species $[26,27]$ and more generally within plant sequence databases [16,28]. CCG/CGG and AGG/ CCT are the most common monocotyledonous EST-SSR motifs $[18,24,29]$ and were under-represented in dicotyledonous species as well as in the present dataset. Kantety et al. [30] have observed that AG/CT predominates among the dinucleotide motifs, presumably reflecting the high frequency of Ala (AGA) and Leu (GAG) (respectively, 8\% and $10 \%)$ in polypeptides [31]. These motifs represented $45.5 \%$ of the eggplant dinucleotide SSRs. The second most abundant motif (36.4\%) was AT/AT, which is also well represented among plant EST sequences [32,33]. Most of the mononucleotide repeats (19/20) were A/T.

The total length of the 64 microsatellite containing sequence reached the $31,909 \mathrm{bp}$. Of this $16,862 \mathrm{bp}$ represented untranslated (UTR) - and 15.047 bp represented protein-coding regions. SSRs were non-randomly distributed among coding regions and UTRs. All of the mononucleotide and majority of the dinucleotide repeats (91\%) were associated with UTRs. Mononucleotide repeats were evenly distributed among 5' and 3' UTRs while dimeric ones preferentially associated with $5^{\prime}$ UTRs. Triplet repeats were significantly over-represented in coding region 
Table I: Occurrence of non-redundant SSRs in a set of 3,357 Solanum melongena sequences.

\begin{tabular}{|c|c|c|c|c|c|c|c|c|c|c|c|c|c|}
\hline \multirow[t]{2}{*}{ SSR motif } & \multicolumn{12}{|c|}{ Number of repeats } & \multirow[t]{2}{*}{ Tota } \\
\hline & 4 & 5 & 6 & 7 & 8 & 9 & 10 & II & 12 & 13 & 14 & $>15$ & \\
\hline $\mathrm{A} / \mathrm{T}$ & - & - & - & - & - & - & - & - & 2 & 3 & 2 & 12 & 19 \\
\hline $\mathrm{C} / \mathrm{G}$ & - & - & - & - & - & - & - & - & 1 & - & - & - & 1 \\
\hline $\mathrm{AC} / \mathrm{GT}$ & - & - & - & I & I & - & - & - & - & - & - & - & 2 \\
\hline AG/CT & - & - & - & 3 & I & - & - & - & - & - & - & - & 4 \\
\hline AT/AT & - & - & - & - & 2 & 2 & - & - & 1 & - & - & - & 5 \\
\hline AAC/GTT & - & I & - & - & - & - & - & - & - & - & - & - & I \\
\hline ACG/CTG & - & 2 & I & - & - & - & - & - & - & - & - & - & 3 \\
\hline AAG/CTT & - & 10 & - & - & - & I & - & - & - & - & - & - & 11 \\
\hline AAT/ATT & - & 1 & - & - & - & - & - & - & - & - & - & 3 & 4 \\
\hline ACC/GGT & - & 2 & - & - & - & - & - & - & - & - & - & - & 2 \\
\hline ACT/ATG & - & 3 & - & 1 & - & - & - & - & - & - & - & - & 3 \\
\hline AGC/CGT & - & 2 & - & - & I & - & - & - & - & - & - & - & 4 \\
\hline AGG/CCT & - & 1 & - & - & - & - & - & - & - & - & - & - & 1 \\
\hline AGT/ATC & - & 5 & - & I & - & - & - & - & - & - & - & - & 6 \\
\hline $\mathrm{CCG} / \mathrm{CGG}$ & - & 1 & - & - & - & - & - & - & - & - & - & - & I \\
\hline AAAT/ATTT & - & - & I & - & - & - & - & - & - & - & - & - & 1 \\
\hline AACCAG/CTTGGT & I & - & - & - & - & - & - & - & - & - & - & - & I \\
\hline ACCAGC/CGTGGT & - & - & 1 & - & - & - & - & - & - & - & - & - & 1 \\
\hline$N$ & - & - & - & - & - & - & - & - & 3 & 3 & 2 & 12 & 20 \\
\hline NN & - & - & - & 4 & 4 & 2 & - & - & 1 & - & - & - & II \\
\hline NNN & - & 28 & I & 2 & I & & - & - & - & - & - & 3 & 36 \\
\hline NNNN & - & $\mathrm{I}$ & - & - & - & - & - & - & - & - & - & - & 1 \\
\hline NNNNNN & 1 & - & 1 & - & - & - & - & - & - & - & - & - & 2 \\
\hline & & & & & & & & & & & & & 70 \\
\hline
\end{tabular}

(75\%) and among non-coding regions showed more than 3 folds greater frequency in 5'UTRs. Such dominance of trimeric over other SSRs in coding regions can be explained by non-perturbation of the reading frame.

\section{SSR assays and their informativeness}

Of the 64 sequences containing one or more SSR, 50 $(78 \%)$ were amenable to primer design. The markers targeted by EEMS01 to EEMS50 comprised 15 mono-, five di-, 24 tri- and two hexanucleotide simple repeats, together with two di- and two trinucleotide compound loci. The remaining sequences contained either too little flanking sequence, or the sequences themselves were refractory for primer design. Thus, primers amplifying non-redundant loci were designed from about $1.4 \%$ of the initial number of database sequences, a success rate comparable to that experienced in other species $[23,26,27]$. Amplicons were generated from genomic DNA template from 39 (78.0\%) of the 50 loci. Failure to amplify can be due to a variety of causes, including the positioning of primers across a splicing site, or to a chimeric origin of the cDNA clones. In all, 31 (79.5\%) of the 39 assays were informative across the whole genotype panel (Table 2), but only 11 (28.2\%) were informative among the sample of cultivated eggplant. The majority of the trinucleotide-containing SSRs were informative between species, but few generated any polymorphism among the cultivated set, while the dinucleotide SSRs identified both inter- and intra-specific polymorphism. Similar results have been reported for eggplant by Nunome et al. $[10,11]$ who described that $57 \%$ of trinucleotide SSRs were informative at inter-, but only $14 \%$ at intraspecific level, while, for the dinucleotide SSRs, the respective frequencies were $78 \%$ and $70 \%$. The repeat type, primer sequence and PIC (polymorphism information content) of the successful markers are given in Table 3.

Generally, amplicon size was in agreement with expectation, although EEMS 26, 31, 39 and 41 all amplified a product at least $100 \mathrm{bp}$ larger than expected, presumably because the amplicon included an intron. EEMS12 produced an amplicon of smaller than expected length, perhaps because of the presence of a deletion within the genomic sequence, poor priming specificity amplifying a non-target member of a gene family, or because of minor sequence variation between the amplified copy and the consensus sequence [34]. A total of 116 alleles was amplified from the full genotype panel, with the number of alleles per locus varying between 1 and 9 (mean 3.1) (Table 
Table 2: Solanum melongena (Sm) genotypes and Solanum related wild species (Sr) assayed (shape and skin colour are indicated in bracket).

\begin{tabular}{|c|c|c|c|}
\hline Species & Genotypes & Use $^{1}$ & codes \\
\hline \multirow[t]{38}{*}{ S. melongena } & Angió3 (Long purple) & $\mathrm{BL}$ & Sm-I \\
\hline & Angió5 (Long green) & $\mathrm{BL}$ & Sm-2 \\
\hline & ANKI (Oval white purple striped) & $\mathrm{BL}$ & Sm-3 \\
\hline & ANK2 (Oval white purple striped) & $\mathrm{BL}$ & Sm-4 \\
\hline & Anominori (Long purple) & $\mathrm{CV}$ & Sm-5 \\
\hline & Baffa (Oval purple) & $\mathrm{CV}$ & Sm-6 \\
\hline & Bianca stirata verde (Small white green striped) & $\mathrm{BL}$ & Sm-7 \\
\hline & Buia (Oblong purple-black) & $\mathrm{BL}$ & Sm-8 \\
\hline & Cannellina Sarnese (Small long purple) & $\mathrm{CV}$ & Sm-9 \\
\hline & CN-2/Qiyeqie (Round purple) & $\mathrm{CV}$ & Sm- 10 \\
\hline & Daizaburou (long purple) & RT & Sm-II \\
\hline & Diataro (round purple) & $\mathrm{RT}$ & Sm- I2 \\
\hline & Dourga (Long white) & $\mathrm{CV}$ & Sm-13 \\
\hline & DR2 (Long dark purple) & $\mathrm{BL}$ & Sm-14 \\
\hline & Gadilak FI (Long purple) & $\mathrm{CV}$ & Sm-I 5 \\
\hline & GIC (Oblongl purple-black) & $\mathrm{BL}$ & Sm- 16 \\
\hline & Hympulse (Long purple-black) & $\mathrm{CV}$ & Sm-17 \\
\hline & JM (Small elongate light purple) & $\mathrm{CV}$ & Sm- 18 \\
\hline & Lunga violetta (Long purple) & $\mathrm{CV}$ & Sm-19 \\
\hline & Lunga violetta napoletana (Long light purple) & $\mathrm{CV}$ & Sm-20 \\
\hline & Maya (Oval purple) & $\mathrm{CV}$ & Sm-2I \\
\hline & Mirabelle (Long purple-black) & $\mathrm{CV}$ & $\mathrm{Sm}-22$ \\
\hline & Mostruosa di New York (Oval purple) & $\mathrm{CV}$ & Sm-23 \\
\hline & Ovale piccola bianca/egg (Small oval white) & $\mathrm{BL}$ & Sm-24 \\
\hline & Palermitana (Oval light purple) & $\mathrm{CV}$ & Sm-25 \\
\hline & Pusa purple cluster (Small elongate purple) & $\mathrm{CV}$ & Sm-26 \\
\hline & Pusa purple long (Long purple) & $\mathrm{CV}$ & Sm-27 \\
\hline & Sita 07 (Oval light purple) & $\mathrm{BL}$ & Sm-28 \\
\hline & SMI9/I4 (Long purple) & $\mathrm{BL}$ & Sm-29 \\
\hline & Tanindo Subur (Long light purple) & $\mathrm{CV}$ & $\mathrm{Sm}-30$ \\
\hline & Tian long (Long purple) & $\mathrm{CV}$ & Sm-31 \\
\hline & Tina (Long dark purple) & $\mathrm{BL}$ & Sm-32 \\
\hline & Tunisina Baharia (Oval light purple) & $\mathrm{CV}$ & $\mathrm{Sm}-33$ \\
\hline & Violetta di Firenze (Oval light purple) & $\mathrm{CV}$ & Sm-34 \\
\hline & Violetta lunga semiorto (Long dark purple) & $\mathrm{CV}$ & Sm-35 \\
\hline & Zihzung FI (Long purple) & $\mathrm{CV}$ & Sm-36 \\
\hline & 305 E40 (Long purple-black) & $\mathrm{BL}$ & Sm-37 \\
\hline & $67-3$ (Oval light purple) & $\mathrm{BL}$ & Sm-38 \\
\hline S. viarum & Japan & & Sr-I \\
\hline S. sodomaeum & Italy & & $\mathrm{Sr}-2$ \\
\hline S. sisymbrifolium & USA & & Sr-3 \\
\hline S. torvum & Indonesia & & Sr-4 \\
\hline S. aethiopicum & France & & Sr-5 \\
\hline S. integrifolium & Japan & & Sr-6 \\
\hline
\end{tabular}

IBL: breeding line; CV: cultivated variety; RT: rootstock.

3). The greatest variation in amplicon size (180-236 bp) was shown by EEMS28. Both the PIC among the 38 cultivated types $\left(\mathrm{PIC}_{\mathrm{m}}\right)$ and among the full 44 genotype set $\left(\mathrm{PIC}_{\mathrm{s}}\right.$ ) were calculated. PIC $\mathrm{m}$ ranged from 0.05 to 0.68 (mean $0.38 \pm 0.12$ ), while $\mathrm{PIC}_{\mathrm{s}}$ varied from 0.04 to 0.76 (mean $0.24 \pm 0.09$ ). The highest and lowest $\mathrm{PIC}_{\mathrm{m}}$ were produced by, respectively, EEMS49 and EEMS20, while EEMS15 had the highest, and EEMS24, 25, 31 and 36 shared the lowest $\mathrm{PIC}_{\mathrm{s}}$. The correlation coefficient between PIC $_{m}$ and SSR length was $0.6(p=0.0001)$, in agreement with the general trend for long SSRs to be more informative than shorter ones [35]. Trinucleotide motif SSRs were less informative than the dinucleotide types (PICs of 0.16 and 0.26 respectively). The former are typically associated with a low level of variability $[18,36]$. The overall level of intraspecific polymorphism uncovered $(28.2 \%)$ is typical [37-39], and compares poorly with the rate achievable by genomic SSR assays $[37,40,41]$. 
Table 3: Allelic variation in 39 SSR loci.

\begin{tabular}{|c|c|c|c|c|c|c|c|c|c|c|}
\hline \multirow[t]{2}{*}{ Code } & \multirow[t]{2}{*}{ Repeat } & \multirow[t]{2}{*}{ FORWARD PRIMER (5'-3') } & \multirow[t]{2}{*}{ REVERSE PRIMER(5'-3') } & \multirow{2}{*}{$\begin{array}{l}\text { Expected } \\
\text { size of } \\
\text { alleles (bp) }\end{array}$} & \multirow{2}{*}{$\begin{array}{c}\text { Allele } \\
\text { size range } \\
\text { (bp) }\end{array}$} & \multicolumn{2}{|c|}{ Nr. of alleles ${ }^{\prime}$} & \multicolumn{2}{|c|}{ PIC $^{2}$} & \multirow{2}{*}{$\begin{array}{c}\text { SSR } \\
\text { position }^{3}\end{array}$} \\
\hline & & & & & & NAI & NA2 & $\mathrm{PICm}$ & PICs & \\
\hline EEMSO6 & $(\mathrm{T}) \mid 4$ & TCATGCGAAGATTAATTAAATGTGA & GAGTGGATGATCAAGAATGGC & 265 & $268-274$ & 1 & 4 & 0 & 0,174 & 3' UTR \\
\hline EEMS07 & $(T) \mid 3$ & CCATGCCAGAATGGAAACTT & AACGAAAACACGATCAACCC & 247 & $250-260$ & 1 & 4 & 0 & 0,209 & 3' UTR \\
\hline EEMSIO & (A) 20 & TCAAGCAGAACGAAGATGGA & GTAGGGGACGTGGATTCAGA & 282 & $266-290$ & 1 & 4 & 0 & 0,174 & 3' UTR \\
\hline EEMSI2 & $(A) 16$ & CGGGCAACTCTTCACATTTT & ATTGGTTTGCTATCGAATTTCT & 158 & $146-150$ & 2 & 3 & 0,097 & 0,273 & 5' UTR \\
\hline EEMSI3 & $(\mathrm{A}) 14$ & TGAGATACGCGTACAATGACTTC & GGGGTTTTGCTGCTGTTATC & 140 & 140 & I & I & 0 & 0 & 5' UTR \\
\hline EEMSI4 & $(\mathrm{A}) 13$ & GGAATGGACCAAACCCCTAA & AGAGCTTCGTTGCTTGGTGT & 277 & $270-276$ & 1 & 3 & 0 & 0,088 & 5' UTR \\
\hline EEMSI5 & (C) 12 & GGGACAAATCTGACCTTTGG & CTGGTGGCAAATTCTTCGAT & 292 & $270-294$ & 5 & 7 & 0,645 & 0,755 & 3' UTR \\
\hline EEMSI6 & $(A C) 7$ & CAATTTTTCGGTTCACTAATCAAG & CTTCAAGGAAAAAGGAGGCC & 132 & $|35-14|$ & 3 & 4 & 0,135 & 0,260 & 3' UTR \\
\hline EEMSI7 & $(\mathrm{CA}) 8$ & TGACATGTAGCTGGGCAGAG & TGGAGTGTGCATCCCAAATA & 197 & $195-197$ & 2 & 2 & 0,492 & 0,499 & 3' UTR \\
\hline EEMSI 8 & $(A G) 7$ & GGAGAAACTGAAAAATTTGTAGAGAG & GAGGAGTTTCCGACATGAGC & 187 & $183-187$ & 1 & 3 & 0 & 0,126 & CDS \\
\hline EEMSI9 & $(\mathrm{AT}) 9$ & GGCATGACAAAATCATACAAACA & TGTTGGTTAAGTCCATGGGAA & 173 & $165-177$ & 1 & 3 & 0 & 0,135 & 3' UTR \\
\hline EEMS20 & (AT)8 & AACATCAGCCAGGGTGTTTC & TGCTGAAAATTACAAGCCAAA & 215 & $221-227$ & 2 & 4 & 0,049 & 0,278 & 3' UTR \\
\hline EEMS2I & $(A G A) 5$ & TGATGTTGAACCGACACAAGA & CGTCTTCATCTTCСTCCTCG & 131 & $122-140$ & 1 & 3 & 0 & 0,126 & CDS \\
\hline EEMS22 & $(\mathrm{AAG}) 5$ & GAAGGACGTTGGTCCTGGTA & CTGTTCATTATCCCCATCGC & 162 & $165-168$ & 1 & 2 & 0 & 0,085 & CDS \\
\hline EEMS23 & (TTC)5 & САССААТTТСССССТТСТTТ & CGGTTGGTAAAGAAAACCCA & 144 & 145 & 1 & 1 & 0 & 0 & CDS \\
\hline EEMS24 & (CTT)5 & CACCTGTTTGAGCACCTTGA & CACCGAAGGCAGAGAAGAAG & 221 & $217-220$ & 1 & 2 & 0 & 0,043 & CDS \\
\hline EEMS25 & (CTT)5 & CCCATAGCTTTGCTCGAGAT & GCACCAAAGGCAGAGAAGAA & 227 & $225-230$ & 1 & 2 & 0 & 0,043 & CDS \\
\hline EEMS26 & (CTT)5 & GACACTCСССТАСТTССАССТ & CGCTTAGCAGAAGCCGATAA & 260 & $355-360$ & 1 & 2 & 0 & 0,087 & CDS \\
\hline EEMS28 & $(\mathrm{TAA}) 21$ & GACGATGACGACGACGATAA & TGGACTCACAACTCAGCCAG & 219 & $180-236$ & 7 & 9 & 0,665 & $0,7 \mid 4$ & 3' UTR \\
\hline EEMS29 & (ATG)5 & TCAGTCAACTGCATCACCAGA & ATTCCCATTATTGGCTGCTG & 118 & 120 & 1 & 1 & 0 & 0 & CDS \\
\hline EEMS30 & $(\mathrm{TAC}) 5$ & TTTACATGACAGCACCAGGC & ATTTTATGGGAATGGGGTCC & 191 & $189-195$ & I & 2 & 0 & 0,087 & 3' UTR \\
\hline EEMS3I & (TGG)5 & GAGAAGTTGGCTTCAGTGCC & TAAACTCAAGGGATGCTGGG & 239 & $330-339$ & 1 & 2 & 0 & 0,043 & CDS \\
\hline EEMS32 & $(\mathrm{TCA}) 5$ & TAAGGAGTCTGATGCCGCTT & GTAATGCTCCTCCACGGCTA & 151 & 150 & 1 & 1 & 0 & 0 & CDS \\
\hline EEMS33 & $(\mathrm{TCA}) 5$ & СTATCTCCTTTTCCCCGACC & ATGAATAAGCTGCCACCACC & 220 & 222 & 1 & 1 & 0 & 0 & CDS \\
\hline EEMS34 & $(\mathrm{TCA}) 5$ & GCTTGATTCCCCACAAAGAA & GTTTCATCGCCCTCATCATT & 276 & $275-278$ & 2 & 2 & 0,123 & 0,143 & CDS \\
\hline EEMS35 & $(\mathrm{TCA}) 5$ & ATGGCTTCTGATGGACCAAG & CACTTGATGAACGTGGATGG & 230 & 232 & 1 & 1 & 0 & 0 & CDS \\
\hline EEMS36 & (TGT)5 & TCTATCATCCCCAGATCCCA & AAGGTCGCATGGACATTAGG & 117 & $110-120$ & 1 & 2 & 0 & 0,043 & CDS \\
\hline EEMS37 & $(\mathrm{TCC}) 5$ & СССТТССТАСССАСАСТТСА & GTTTTGCACCTTTCCATCGT & 117 & $114-123$ & 2 & 4 & 0,375 & 0,502 & CDS \\
\hline
\end{tabular}


Table 3: Allelic variation in 39 SSR loci. (Continued)

\begin{tabular}{|c|c|c|c|c|c|c|c|c|c|c|}
\hline EEMS38 & $(\mathrm{CAC}) 5$ & TTCAATCGAACTTCGGAACC & ATGACGGTGGATCTCGCTAC & 148 & $135-153$ & I & 3 & 0 & 0,086 & CDS \\
\hline EEMS39 & (CTG)5 & GGAGAGATGGATGCCGAATA & TCTCGACCTTAGCCTGCATT & 166 & $264-270$ & I & 3 & 0 & 0,126 & CDS \\
\hline EEMS4I & $(\mathrm{GCA}) 5$ & ATTCTGCATTCATCGGAAGG & GGATTGCTTGTGGGAATATCA & 260 & 700,1600 & 1 & 1 & 0 & 0 & CDS \\
\hline EEMS42 & $(\mathrm{GCA}) 6$ & GCTCAGCAACCACAGTACCA & GTCCGGACTTCATCAGCATT & 152 & $155-180$ & 1 & 3 & 0 & 0,166 & CDS \\
\hline EEMS44 & $(G C C) 5$ & ССТТСАААСССТСТСССТТС & GTGAAACGTGGTGGAGGTCT & 216 & 215 & I & 1 & 0 & 0 & CDS \\
\hline EEMS45 & $($ AGAACC) 4 & AGCGCTTGTCCAGGCTATAA & TTTCCACCATGAGCAAATGA & 282 & $279-285$ & I & 2 & 0 & 0,197 & \\
\hline EEMS46 & $(\mathrm{ACCAGC}) 6$ & ACCAAACGTGCATGAAACAA & GGAAATGTTGGTGGAATTGG & 264 & $245-265$ & 1 & 4 & 0 & 0,207 & CDS \\
\hline EEMS47 & (GCT)5..(TTC)5 & CGAACACATTCGCAAATCAC & GCATCACAAGGATGGAAAGG & 246 & $250-253$ & 1 & 2 & 0 & 0,162 & CDS \\
\hline EEMS48 & $(T A A) 20(C G A) 8$ & CAATGCAAACAATTATCATTTCG & TCGATGTTGTTGTCGTCGTT & 213 & $223-241$ & 7 & 9 & 0,641 & 0,677 & 3' UTR \\
\hline EEMS49 & $(\mathrm{TA}) \mid 2(\mathrm{GA}) 7$ & TGAAATTGATCAATACCTATAAATTTAG & GAAAGCCAGGATAGCATTCG & 140 & $145-153$ & 5 & 5 & 0,677 & 0,677 & 3' UTR \\
\hline EEMS50 & $(\mathrm{TA}) 9(\mathrm{GA}) 8$ & AAATCCGGCCATTCTGTGTA & ACATCGTTCCGCCTCTATTG & 224 & $218-226$ & 2 & 4 & 0,229 & 0,377 & 5' UTR \\
\hline
\end{tabular}

I NAI: number of alleles detected among the 38 cultivated types, NA2: number of alleles detected among the full 44 genotype set; ${ }^{2}$ PICm: calculated among the 38 cultivated types, PICs: calculated among the full 44 genotype set; ${ }^{3} \mathrm{CDS}$ : Coding sequence 


\section{Genetic diversity revealed by SSR markers}

Thiel et al [24] have stressed the limitations surrounding the application of SSR markers for diversity studies, emphasising the possibility of homoplasy (identical allele sizes may not be identical by descent), and have pointed out that allele size differences can also be generated by indel events, as well as by variation in the SSR repeat number. However, the genetic relationships between the accessions of the full genotype panel as displayed by genetic similarity at the SSR level were in good agreement with prior taxonomic classification based on both genomic $[9,11]$ and plastidial markers $[42,43]$. Thus the cultivated eggplants clustered with an average genetic similarity of $82 \%$ (Figure 1). Three pairs of cultivars ('Tina' and 'Dourga'; 'Sita 07' and 'Violetta di Firenze'; 'Mostruosa di New York' and '305 E40') and 'Mirabelle', 'DR2' and 'Lunga violetta napoletana' were identical to one another. The cluster closest to the cultivated group contained both $S$. viarum and $S$. sodomaeum, with a mean genetic differentiation of $\sim 50 \%$ from the cultivated germplasm. The S. torvum accession was more distant (mean genetic similarity 39\%). The third cluster contained the remaining species $S$. sisymbrifolium, aethiopicum and integrifolium which shared a mean genetic similarity of $56 \%$.

The EEMS primers were also applied to amplify template from potato, tomato and pepper, which all belong to the Solanaceae. To minimise non-specific amplification, the same stringency level for PCR was applied as with eggplant template. About 54\% (21 of the primer pairs) generated a detectable amplicon from at least one of the three species; ten of 21 amplified all three templates, seven amplified potato and tomato but not pepper DNA, two tomato and pepper but not potato, and one each amplified only from potato and tomato.

The principal co-ordinate analysis (PCO) analysis illustrates the genetic relationships between the members of the genotype panel (Figure 2). The first three principal coordinates accounted for $\sim 54 \%$ of the overall genetic variation, with each in turn contributing 34.2\%, 10.3\% and 9.4\%. The first co-ordinate distinguished the cultivated forms from the allied genotypes, while the second allowed the separation of each related eggplant genotypes.

\section{BLAST analyses}

Of the 39 functional SSR markers, all but EEMS45 were developed from anonymous eggplant unigene sequences, 25 of which share significant homology to Arabidopsis thaliana proteins of unknown function. EEMS45 lies within a chloroplast phosphate transporter gene (Table 4). Using the source eggplant sequences as a BLASTN query (the target database has been described in the 'Method' section), 24 (61.5\%) of the markers identified highly conserved orthologs, with a frequency negatively correlated with phylogenetic distance from eggplant [44]. EEMS15, EEMS21, EEMS24, EEMS39, and EEMS45 had homologous counterparts with known function. Sequences containing homologous microsatellite motifs in conserved positions were found in 15 potato, 10 tomato and 1 pepper orthologs (Table 4). Contrasting results are reported in literature on the transferability of microsatellite markers across members of the Solanaceae $[26,45,46]$. The high level of transferability between the seven Solanum spp. mirrors the experience in other groups of plants [47]; furthermore we detect a low level of intraspecific polymorphism which seems to confirm the conclusion that EST-SSRs are highly conserved across species [48].

\section{Conclusion}

In eggplant, as in pepper and tomato $[3,49,50]$, the level of intraspecific DNA marker polymorphism is rather limited. Nunome et al [11] constructed a genetic map in eggplant based on RAPD and AFLP markers, but only $8.3 \%$ of the RAPD primers were informative, and even the AFLP primer combinations were only able to deliver a mean of 2.4 polymorphisms each. We have shown that an in silico analysis of the albeit limited quantity of publicly available eggplant DNA sequence has enabled the development of a set of functional SSR markers. Because these sequences are derived from the expressed portion of the genome, they are relevant for assaying functional diversity in populations or germplasm collections. Most of the EEMS SSRs are readily transferable to related species, and so can be exploited as anchor markers for comparative mapping and evolutionary studies.

\section{Methods \\ Mining of SSR-containing sequences and primer design}

In all, 3,357 eggplant sequences were retrieved from the SGN and EMBL nucleotide databases, using the Sequence Retrieval System (SRS6, http://srs.ebi.ac.uk/). A standalone nucleotide database was built for local BLAST2 searches [51]. PolyA and polyT tracts were removed, by applying the criterion that no $50 \mathrm{bp}$ window contain a run of ten A's or ten T's. ClustalW [52] alignment was used to eliminate redundancy, by setting the following two criteria: (i) where a cluster contained two or more identical sequences, the longest was retained, and (ii) where the members of a cluster fell into recognisable sub-groups, only one member of each sub-group was retained. Sequences composed entirely of SSR motif (i.e., lacking any flanking sequence) were discarded, since their uniqueness could not be established, and in any case, primer design is not possible. SSR-containing sequences were identified using MISA software [24], a Perl script which allows both perfect and compound SSRs to be detected. A sequence was considered an SSR where a motif 


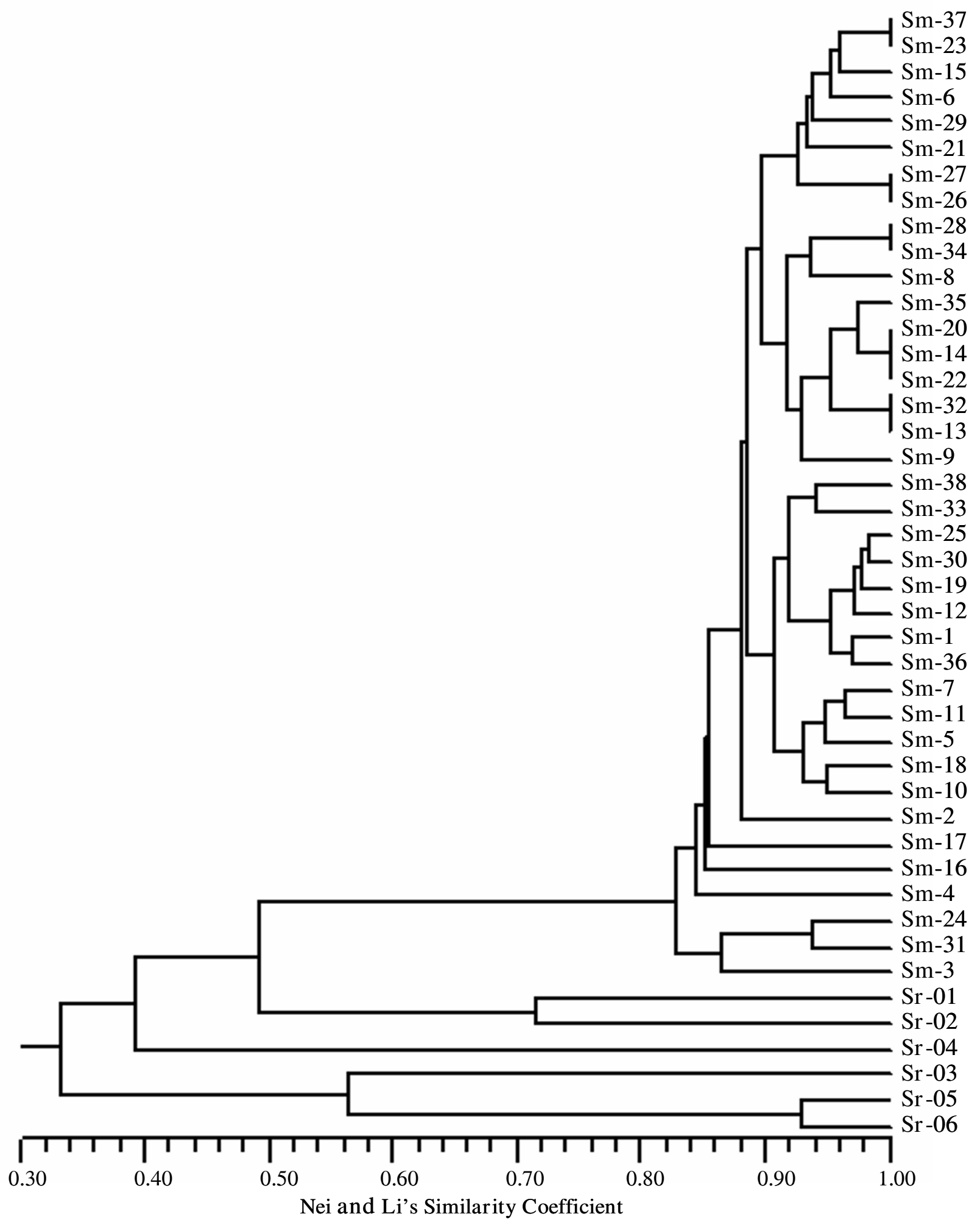

Figure I

UPGMA dendrogram. Analysis of the 44 genotype set, based on I I6 EST-SSR alleles. Sample codes are described in Table 2. 


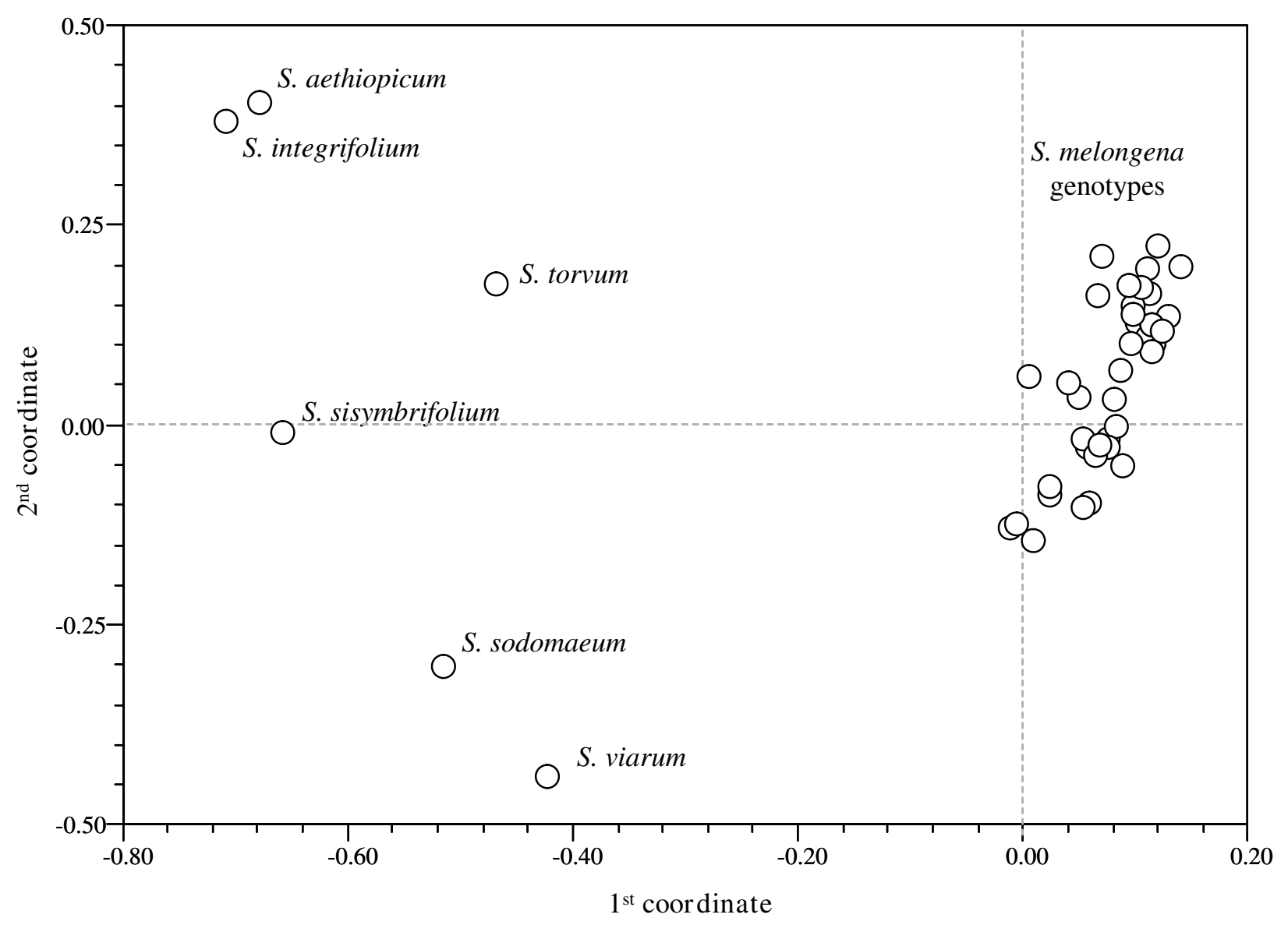

Figure 2

Biplot of the Principal co-ordinates analysis. Analysis based on microsatellite data depicting the genetic relationship among the 44 Solanum genotypes.

was repeated at least 12 times ( 1 nt motif), seven times ( 2 $\mathrm{nt})$ or five times (3-6 nt), allowing for only one mismatch. For compound repeats, the maximum default interruption (spacer) length was set at $100 \mathrm{bp}$.

Primer pairs were designed from the flanking sequences, using PRIMER3 software [53] in batch mode via the p3_in.pl and p3_out.pl Perl5 scripts within the MISA package. The target amplicon size was set as $100-300 \mathrm{bp}$, the optimal annealing temperature as $60^{\circ} \mathrm{C}$, and the optimal primer length as $20 \mathrm{bp}$. The resulting markers were each assigned the prefix EEMS (EST Eggplant MicroSatellite). Local BLASTN analyses were carried out using all EEMS sequences as queries. The target database contained $1,524,584$ entries derived from a variety of solanaceous species, retrieved from the EMBL sequence database (Release 93)

\section{Plant material, DNA extraction and PCR}

EEMS informativeness was evaluated using a panel of 44 accessions, made up from 38 cultivated eggplant varieties, breeding lines and rootstocks, and six related wild Solanum species (Table 2). Cross-species transferability was tested against tomato, pepper and potato DNA. DNA was isolated from young leaves using the method described by Doyle and Doyle [54]. PCR amplification was carried out in $20 \mu \mathrm{l}$ reactions, each containing $10 \mathrm{ng}$ genomic DNA, $10 \mathrm{nmol} / \mathrm{L}$ Tris-HCl (pH 8.3), $50 \mathrm{mmol} / \mathrm{L} \mathrm{KCl}, 2.5 \mathrm{mmol} /$ $\mathrm{L} \mathrm{MgCl}$, $0.5 \mathrm{U}$ Taq polymerase, $0.2 \mathrm{mmol} / \mathrm{L} \mathrm{dNTP,} 200$ nmol/L unlabeled reverse primer and $200 \mathrm{nmol} / \mathrm{L}$ IRD700-labelled forward primer. A touchdown PCR protocol was applied, consisting of a $94^{\circ} \mathrm{C} / 5 \mathrm{~min}$ denaturation, 11 cycles of $94^{\circ} \mathrm{C} / 30 \mathrm{~s}, 60^{\circ} \mathrm{C} / 30 \mathrm{~s}$ decreasing by $0.5^{\circ}$ per cycle, and $72^{\circ} \mathrm{C} / 60 \mathrm{~s}$, followed by 30 cycles of $94^{\circ} \mathrm{C} /$ $30 \mathrm{~s}, 55^{\circ} \mathrm{C} / 30 \mathrm{~s}$ and $72^{\circ} \mathrm{C} / 60 \mathrm{~s}$. The success of each amplification was monitored by analysis of the reaction product following $2 \%$ agarose gel electrophoresis, and successful 
Table 4: Homology relationships of the EEMS markers.

\begin{tabular}{|c|c|c|c|c|c|c|}
\hline Marker & SGN Unigene ID & $\begin{array}{c}\text { Homologous Arabi- } \\
\text { dopsis peptide }\end{array}$ & $\begin{array}{c}\text { Homologous ESTs in } \\
\text { tomato, potato or } \\
\text { pepper } \\
\text { (GenBank ID) }\end{array}$ & Annotation & e-value & $\begin{array}{l}\text { SSR in the same } \\
\text { position }\end{array}$ \\
\hline \multirow[t]{2}{*}{ EEMSO6 } & U206099 & & DN587316 & $\begin{array}{l}\text { 47382. I Late Blight- } \\
\text { Challenged Tubers Solanum } \\
\text { tuberosum cDNA clone } \\
47382\end{array}$ & e- 100 & \\
\hline & & & AW02973I & $\begin{array}{l}\text { EST272986 tomato callus, } \\
\text { TAMU Lycopersicon } \\
\text { esculentum cDNA clone } \\
\text { cLEC28K } 19\end{array}$ & $7 e-80$ & \\
\hline \multirow[t]{3}{*}{ EEMSO7 } & U206473 & At3g55570.1 & CV506255 & $\begin{array}{l}\text { 72934.I Mixed Floral } \\
\text { Solanum tuberosum cDNA } \\
\text { clone } 72934\end{array}$ & $2 e-77$ & \\
\hline & & & CA525885 & $\begin{array}{l}\text { KSI2063A07 KSI2 } \\
\text { Capsicum annuum cDNA }\end{array}$ & le-75 & \\
\hline & & & AK224899 & $\begin{array}{l}\text { Solanum lycopersicum } \\
\text { cDNA, clone: FC25DG07, } \\
\text { HTC in fruit }\end{array}$ & $6 e-65$ & \\
\hline EEMSIO & U206024 & & $\underline{\mathrm{CK} 274806}$ & $\begin{array}{l}\text { EST720884 potato abiotic } \\
\text { stress cDNA library } \\
\text { Solanum tuberosum cDNA } \\
\text { clone POADJ52 }\end{array}$ & $e-164$ & + \\
\hline \multirow[t]{3}{*}{ EEMSI4 } & U205878 & AtCg00070.I & $\underline{D Q 347958}$ & $\begin{array}{l}\text { Solanum bulbocastanum } \\
\text { cultivar PT2 } 29 \text { chloroplast, } \\
\text { complete genome }\end{array}$ & 0.0 & \\
\hline & & & DQ347959 & $\begin{array}{l}\text { Lycopersicon esculentum } \\
\text { cultivar LA3023 } \\
\text { chloroplast, complete } \\
\text { genome }\end{array}$ & 0.0 & + \\
\hline & & & ER831875 & $\begin{array}{l}\text { PPTC658TF Solanum } \\
\text { tuberosum RHPOTKEY } \\
\text { BAC ends Solanum } \\
\text { tuberosum genomic clone } \\
\text { RHPOTKEYI38_I9, } \\
\text { genomic survey sequence }\end{array}$ & 0.0 & + \\
\hline \multirow[t]{2}{*}{ EEMSI5 } & U207285 & At|g15820.I & B1435095 & $\begin{array}{l}\text { EST537856 P. infestans- } \\
\text { challenged potato leaf, } \\
\text { compatible reaction } \\
\text { Solanum tuberosum cDNA } \\
\text { clone PPCBZ49 }\end{array}$ & e-139 & \\
\hline & & & M32605 & $\begin{array}{l}\text { Tomato chlorophyll a- } \\
\text { binding protein (CabI0A) } \\
\text { gene }\end{array}$ & e- 124 & \\
\hline \multirow[t]{2}{*}{ EEMSI7 } & U206974 & At5g53360.I & AA824717 & $\begin{array}{l}\text { CT008.SK Tomato Leaf } \\
\text { cDNA from cv. VFNT } \\
\text { cherry Lycopersicon } \\
\text { esculentum cDNA clone } \\
\text { CT008 }\end{array}$ & |e-7| & + \\
\hline & & & DN58726I & $\begin{array}{l}\text { 47295. I Late Blight- } \\
\text { Challenged Tubers Solanum } \\
\text { tuberosum cDNA clone } \\
47295\end{array}$ & $3 e-60$ & \\
\hline EEMSI 8 & U205890 & At lg08200.I & B1932492 & $\begin{array}{l}\text { EST55238I tomato flower, } \\
8 \mathrm{~mm} \text { to preanthesis buds } \\
\text { Lycopersicon esculentum } \\
\text { cDNA clone cTOC23G } 4\end{array}$ & 0.0 & \\
\hline EEMS20 & U206004 & At5g52990.I & & & & \\
\hline EEMS2I & U207374 & At3g56860.3 & DQ284462 & $\begin{array}{l}\text { Solanum tuberosum clone } \\
\text { 072A05 RNA-binding } \\
\text { protein AKIPI -like mRNA }\end{array}$ & e- 148 & \\
\hline EEMS22 & U206874 & Atlg07790.I & $\underline{A C 204499}$ & $\begin{array}{l}\text { Solanum tuberosum } \\
\text { chromosome } 6 \text { clone } \\
\text { RHPOTKEY069BI2 }\end{array}$ & e- 129 & + \\
\hline
\end{tabular}


Table 4: Homology relationships of the EEMS markers. (Continued)

\begin{tabular}{|c|c|c|c|c|c|c|}
\hline & & & Al778436 & $\begin{array}{l}\text { EST2593I5 tomato } \\
\text { susceptible, Cornell } \\
\text { Lycopersicon esculentum } \\
\text { cDNA clone cLES5G8 }\end{array}$ & e- 127 & + \\
\hline & & & CA524430 & $\begin{array}{l}\text { KSI2037DI2 KSI2 } \\
\text { Capsicum annuum cDNA, } \\
\text { mRNA sequence }\end{array}$ & e-1II & \\
\hline \multirow[t]{2}{*}{ EEMS23 } & U207287 & At2g25080.I & BQII34II & $\begin{array}{l}\text { EST598987 mixed potato } \\
\text { tissues Solanum tuberosum } \\
\text { cDNA clone STMCN43 }\end{array}$ & e- 126 & + \\
\hline & & & ES890426 & $\begin{array}{l}\text { LET0I IF7_2005-09-27_I/ } \\
\text { LET0I IF7_AI2_I Solanum } \\
\text { lycopersicum trichomes }\end{array}$ & e- 114 & + \\
\hline EEMS24 & U2056I2 & At5g59910.1 & DQ268853 & $\begin{array}{l}\text { Solanum tuberosum clone } \\
\text { I67E08 histone H2B-like } \\
\text { protein mRNA }\end{array}$ & 0.0 & + \\
\hline \multirow[t]{2}{*}{ EEMS25 } & U205886 & At5g59910.1 & BG643224 & $\begin{array}{l}\text { EST5I I } 4 \text { I } 8 \text { tomato shoot/ } \\
\text { meristem Lycopersicon } \\
\text { esculentum cDNA clone } \\
\text { cTOF26PI2 5' sequence }\end{array}$ & e- 102 & + \\
\hline & & & CV501903 & $\begin{array}{l}66441.1 \text { Mixed Floral } \\
\text { Solanum tuberosum cDNA } \\
\text { clone } 6644 \text { I }\end{array}$ & $3 e-86$ & + \\
\hline EEMS26 & U205659 & At5g05270.2 & & & & \\
\hline EEMS28 & U205759 & At5g20950.2 & CK262774 & $\begin{array}{l}\text { EST708852 potato abiotic } \\
\text { stress cDNA library } \\
\text { Solanum tuberosum cDNA } \\
\text { clone POABI35 }\end{array}$ & e- 143 & + \\
\hline EEMS29 & U206036 & At5g38050.I & BP877982 & $\begin{array}{l}\text { Solanum lycopersicum } \\
\text { cDNA, clone: FA IOBF05, 5' } \\
\text { end, expressed in maturing } \\
\text { fruit }\end{array}$ & $7 e-98$ & + \\
\hline EEMS30 & U206347 & & BQ508532 & $\begin{array}{l}\text { EST615947 Generation of a } \\
\text { set of potato cDNA clones } \\
\text { for microarray analyses } \\
\text { mixed potato tissues } \\
\text { Solanum tuberosum cDNA } \\
\text { clone STMGW83 }\end{array}$ & $e-112$ & + \\
\hline \multirow[t]{2}{*}{ EEMS3I } & U20603I & At2g277। 0.2 & CV469914 & $\begin{array}{l}\text { 42678.I Common Scab- } \\
\text { Challenged Tubers Solanum } \\
\text { tuberosum cDNA clone } \\
42678\end{array}$ & 0.0 & + \\
\hline & & & DB680885 & $\begin{array}{l}\text { Solanum lycopersicum } \\
\text { cDNA, clone: } \\
\text { LEFLI008CF04, 5' end, } \\
\text { expressed in leaf }\end{array}$ & 0.0 & + \\
\hline EEMS32 & U2070I5 & At4g 19430.1 & & & & \\
\hline \multirow[t]{2}{*}{ EEMS35 } & U205935 & Atlg62045.I & CK86I590 & $\begin{array}{l}32687 \text { In vitro Root } \\
\text { Solanum tuberosum cDNA }\end{array}$ & e- 105 & + \\
\hline & & & $A C 215407$ & $\begin{array}{l}\text { Solanum lycopersicum } \\
\text { Tomato chromosome } 2 \text {, } \\
\mathrm{C} 02 \mathrm{HBa} 0 \mathrm{I} 67 \mathrm{~J} 2 \mathrm{I} \text {, complete } \\
\text { sequence. }\end{array}$ & $8 e-89$ & \\
\hline EEMS37 & U206679 & At5g64280.I & & & & \\
\hline EEMS38 & U205635 & At2g21660.I & CK277760 & $\begin{array}{l}\text { EST723838 potato abiotic } \\
\text { stress cDNA library } \\
\text { Solanum tuberosum cDNA } \\
\text { clone POAEI } 72\end{array}$ & $e-113$ & + \\
\hline EEMS39 & U2065I4 & At5g5II20.I & Al482858 & $\begin{array}{l}\text { EST242I8I tomato shoot, } \\
\text { Cornell Lycopersicon } \\
\text { esculentum cDNA clone } \\
\text { cLEB3D24 similar to RNA } \\
\text { binding protein }\end{array}$ & e- 108 & + \\
\hline
\end{tabular}


Table 4: Homology relationships of the EEMS markers. (Continued)

\begin{tabular}{|c|c|c|c|c|c|c|}
\hline \multirow[t]{2}{*}{ EEMS42 } & U206785 & At $\lg \mid 1650.1$ & CK27I457 & $\begin{array}{l}\text { EST7I7535 potato abiotic } \\
\text { stress cDNA library } \\
\text { Solanum tuberosum cDNA } \\
\text { clone POACZ28 }\end{array}$ & $e-132$ & + \\
\hline & & & Al78I607 & $\begin{array}{l}\text { EST262486 tomato } \\
\text { susceptible, Cornell } \\
\text { Lycopersicon esculentum } \\
\text { cDNA clone cLESI6F7 }\end{array}$ & e- 125 & + \\
\hline EEMS44 & U205885 & At2g43090.I & CK276247 & $\begin{array}{l}\text { EST722325 potato abiotic } \\
\text { stress cDNA library } \\
\text { Solanum tuberosum cDNA } \\
\text { clone POADS32 5' end, } \\
\text { mRNA sequence. }\end{array}$ & e- 148 & + \\
\hline \multirow[t]{3}{*}{ EEMS45 } & U94558 & & BQ04760I & $\begin{array}{l}\text { P. infestans-challenged } \\
\text { potato leaf, incompatible } \\
\text { reaction Solanum } \\
\text { tuberosum cDNA clone } \\
\text { BPLII8O9 }\end{array}$ & 0.0 & + \\
\hline & & & EF094557 & $\begin{array}{l}\text { Capsicum frutescens } \\
\text { chloroplast phosphate } \\
\text { transporter (Pht2;I) }\end{array}$ & 0.0 & + \\
\hline & & & BE433007 & $\begin{array}{l}\text { EST399536 tomato breaker } \\
\text { fruit, TIGR Lycopersicon } \\
\text { esculentum cDNA clone } \\
\text { cLEG I IHI I }\end{array}$ & $2 e-98$ & + \\
\hline EEMS48 & U205759 & At5g20950.2 & & & & \\
\hline EEMS49 & U206896 & & El386298 & $\begin{array}{l}\text { POTCQ36TF Solanum } \\
\text { tuberosum RHPOTKEY } \\
\text { BAC ends Solanu } \\
\text { tuberosum genomic clone } \\
\text { RHPOTKEY025_F23, } \\
\text { genomic survey sequence. }\end{array}$ & le-37 & \\
\hline \multirow[t]{2}{*}{ EEMS50 } & U205674 & At2g43360.I & BFI87639 & $\begin{array}{l}\text { EST443926 potato stolon, } \\
\text { Cornell University Solanum } \\
\text { tuberosum cDNA clone } \\
\text { cSTA4 IB6 }\end{array}$ & 0.0 & + \\
\hline & & & B1935563 & $\begin{array}{l}\text { EST555452 tomato flower, } \\
\text { anthesis Lycopersicon } \\
\text { esculentum cDNA clone } \\
\text { cTOD23C22 }\end{array}$ & e- 167 & \\
\hline
\end{tabular}

amplicons were separated by denaturing $6 \%$ polyacrylamide gel electrophoresis on a LI-COR Gene ReadIR 4200 device, as described by Jackson and Matthews [55]. Determination of amplicon size was achieved by including an IRD700-labelled 50-350 bp ladder in each well. The data were collected by e-Seq software (DNA Sequencing and Analysis Software) v3.0.

\section{Data analysis}

The polymorphism information content (PIC) of an SSR combines the number of alleles and their frequency distribution within a population [56]. For the present purposes, it was estimated as by Anderson et al. [57]. The SSR products were scored as band presence (1) and absence (0), thus generating a binary matrix. The binary data matrix was used to compute pair-wise similarity coefficients [58], and the similarity matrices obtained were utilized to construct a UPGMA-based dendrogram [58]. Principal co-ordinate analysis (PCO) was carried out to display the multi-dimensional relationship between accessions. All analyses were performed using the NYSYS software package v2.10 [60].

\section{Authors' contributions}

SL and GLR planned and supervised the work. AS carried out SSR mining, primer design and amplification; LT and GLR provided plant materials; EP carried out the analysis of data. All the authors contributed to the final version of the manuscript.

\section{References}

I. Daunay MC, Lester RN, Ano G: Cultivated eggplants. In tropical plant breeding Edited by: Charpier A, Jacquot M, Hamon S, Nicolas D. Oxford university press, Oxford; 2001:200-225.

2. Hinata H: Eggplant (Solanum melongena L.). In Biotechnology in agriculture and Forestry, Crop I Volume 2. Edited by: Bajaj YPS. Springer, Berlin; 1986:363-370.

3. Barchi L, Bonnet J, Boudet C, Signoret P, Nagy I, Lanteri S, Palloix A, Lefebvre $V$ : A high-resolution intraspecific linkage map of pepper (Capsicum annuum L.) and selection of reduced RIL subsets for fast mapping. Genome 2007, 50:5I-60.

4. Jacobs JME, Van Eck HJ, Arens P, Verkerk-Bakker B, Lintel B, Hekkert HJM, Bastiaanssen A, El-Kharbotly A, Pereira E, Jacobsen E, Stiekema WJ: A genetic map of potato (Solanum tuberosum) integrating 
molecular markers, including transposons, and classical markers. TAG 2004, $91: 289-300$.

5. Tanksley SD, Ganal MW, Prince JP, Vicente MC, Bonierbale MW Broun P, Fulton TM, Giovannoni J], Grandillo S, Martin GB, Messeguer R, Miller JC, Miller L, Paterson AH, Pineda O, Roder MS, Wing RA, $\mathrm{Wu}$ W, Young ND: High density molecular linkage maps of the tomato and potato genomes. Genetics 1992, |32: | |4|-| | 60.

6. Livingstone KD, Lackney VK, Blauth JR, Wijk RV, Jahn MK: Genome mapping in Capsicum and the evolution of genome structure in the Solanaceae. Genetics 1999, I52:1 |83-1202.

7. Karihaloo JL, Brauner S, Gottlieb LD: Random amplified polymorphic DNA variation in the eggplant, Solanum melongena L. (Solanaceae). Theor Appl Genet 1995, 90:767-770.

8. Mace ES, Lester RN, Gebhardt CG: AFLP analysis of genetic relationship among the cultivated eggplant Solanum melongena L. and wild relatives (Solanaceae). Theor Appl Genet 1999, 99:626-633.

9. Furini A, Wunder J: Analysis of eggplant (Solanum melongena) related germplasm: morphological and AFLP data contribute to phylogenetic interpretations and germplasm utilizations. Theor Appl Genet 2004, I 08: 197-208.

10. Nunome T, Suwabe K, Ohyama A, Fukuoka H: Characterization of trinucleotide microsatellites in Eggplant. Breeding Science 2003, 53:77-83.

II. Nunome T, Suwabe K, Iketani H, Hirai M: Identification and characterization of microsatellites in eggplant. Plant Breeding 2003 1 22:256-262.

12. Nunome T, Ishiguro K, Yoshida T, Hirai M: Mapping of fruit shape and color development traits in eggplant (Solanum melongena L.) based on RAPD and AFLP markers. Breeding Science 200I, 5I:19-26.

13. Doganlar S, Frary A, Daunay MC, Lester RN, Tanksley SD: A comparative genetic linkage map of Eggplant (Solanum melongena) and its implications for genome evolution in the Solanaceae. Genetics 2002, 161:1697-1711.

14. Powell W, Machray G, Provan J: Polymorphism revealed by simple sequence repeats. Trends Plant Sci 1996, I:215-222.

15. Morgante M, Hanafey M, Powell W: Microsatellites are preferentially associated with nonrepetitive DNA in plant genome. Nat Genet 2002, 30: 194-200.

16. Toth G, Gaspari Z, Jurka J: Microsatellites in different eukaryotic genomes: survey and analysis. Genom Res 2000, 10:967-981.

17. Varshney RK, Sigmund R, Boerner A, Korzun V, Stein N, Sorrells M, Langridge $P$, Graner A: Interspecific transferability and comparative mapping of barley EST-SSR markers in wheat, rye and rice. Plant Sci 2005, 168:195-202.

18. Cho YG, Ishii T, Temnykh S, Chen X, Lipovich L, McCouch SR, Park WD, Ayer N, Cartinhour S: Diversity of microsatellites derived from genomic libraries and GenBank sequences in rice (Oryza sativa). Theor Appl Genet 2000, 100:71 3-722.

19. Chabane K, Ablett A, Cordeiro GM, Valkoun J, Henry RJ: EST versus genomic derived microsatellite markers for genotyping wild and cultivated barley. Genet Resour Crop Evol 2005 , 52:903-909.

20. Andersen $\mathrm{JR}$, Lubberstedt $\mathrm{T}$ : Functional markers in plants. Trends Plant Sci 2003, 8:554-560.

21. Varshney RK, Thiel T, Stein N, Langridge P, Graner A: In silico analysis on frequency and distribution of microsatellites in ESTs of some cereal species. Cell Mol Biol Lett 2002, 7:537-546.

22. Kumpatla PS, Mukhopadhyay S: Mining and survey of simple sequence repeats in expressed sequence tags of dicotyledonous species. Genome 2005, 48:985-998.

23. Chen C, Zhou P, Choi YA, Huang S, Gmitter FG Jr: Mining and characterizing microsatellites from citrus ESTs. Theor Appl Genet 2006, I I 2: | 248-1257.

24. Thiel T, Michalek W, Varshney RK, Graner A: Exploiting EST databases for the development and characterization of genederived SSR-markers in barley (Hordeum vulgare L.). Theor Appl Genet 2003, 106:4II-422.

25. Metzgar D, Bytof J, Willis C: Selection against frameshift mutations limits microsatellite expansion in coding DNA. Genome Res 2000, 10:72-80.

26. Nagy I, Stágel A, Sasvári Z, Röder M, Ganal M: Development, characterization, and transferability to other Solanaceae of microsatellite markers in pepper (Capsicum annuum L.). Genome 2007, 50:668-688.
27. Portis E, Nagy I, Sasvári Z, Stágel A, Barchi L, Lanteri S: The design of Capsicum spp. SSR assays via analysis of in silico DNA sequence, and their potential utility for genetic mapping. Plant Science 2007, 172:640-648.

28. Katti MV, Prabhakar KR, Gupta VS: Differential distribution of simple sequence repeats in eukaryotic genome sequences. Mol Biol Evol 200I, 18:1161-I167.

29. Chin ECL: Maize simple repetitive DNA sequences: abundance and allele variation. Genome 1996, 39:866-873.

30. Kanety RV, Rota ML, Matthews DE, Sorrells ME: Data mining for simple sequence repeats in expressed sequence tags from barely, maize, rice, sorghum and wheat. Plant Mol Biol 2002, 48:50I-5IO

31. Lewin BV: Genes, Oxford University Press, New York; 1994.

32. Lagercrantz $U$, Ellegren $H$, Andersson $L$ : The abundance of various polymorphic microsatellite motifs differs between plants and vertebrates. Nucleic Acids Res 1993, 21: I I I I- I I I5.

33. Morgante M, Olivieri AM: PCR-amplified microsatellites as markers in plant genetics. Plant $J$ 1993, 3:175- I82

34. Nicot N, Chiquet V, Gandon B, Amilhat L, Legeai F, Leroy P, Bernard $M$, Sourdille $P$ : Study of simple sequence repeat (SSR) markers from wheat expressed sequence tags (ESTs). Theor Appl Genet 2004, 109:800-805.

35. Weber JL: Informativeness of human (dC-dA)n.(dG-dT)n polymorphism. Genomics 1990, 7:524-530.

36. Liewlaksaneeyanawin C, Ritland CE, El-Kassaby YA, Ritland K: Single-copy, species-transferable microsatellite markers developed from loblolly pine ESTs. Theor Appl Genet 2004, 109:361-369.

37. Eujayl I, Sorrells ME, Baum M, Wolters P, Powell W: Isolation of EST-derived microsatellite markers for genotyping the $A$ and B genomes of wheat. Theor Appl Genet 2002, 104:399-407.

38. Park YH, Alabady MS, Ulloa M, Sickler B, Wilkins TA, Yu J, Stelly DM, Kohel RJ, El-Shihy OM, Cantrell RG: Genetic mapping of new cotton fiber loci using EST-derived microsatellites in an interspecific recombinant inbred line cotton population. Mol Genet Genom 2005, 274:428-44I.

39. Han Z, Guo W, Song X, Zhang T: Genetic mapping of ESTderived microsatellites from the diploid Gossypium arboreum in allotetraploid cotton. Mol Genet Genom 2004, 272:308-327.

40. Reddy OUK, Pepper AE, Abdurakhmonov I, Saha S, Jenkins JN, Brooks T, Bolek Y, El-Zik KM: New dinucleotide and trinucleotide microsatellite marker resources for cotton genome research. J Cotton Sci 200I, 5:103-II3.

4I. Nguyen TB, Giband M, Brottier P, Risterucci AM, Lacape JM: Wide coverage of the tetraploid cotton genome using newly developed microsatellite markers. Theor Appl Genet 2004, 109:167-175.

42. Isshiki S, Uchiyama T, Tashiro Y, Miyazaki S: RFLP analysis of a PCR amplified region of chloroplast DNA in eggplant and related Solanum species. Euphytica 1998, 102:295-299.

43. Isshiki S, Suzuki S, Yamashita K: RFLP analysis of mithocondrial DNA in eggplant and related Solanum species. Genetic research and crop evolution 2003, 50: 133-137.

44. Olmstead RG, Palmer JD: Implications for the phylogeny, classification, and biogeography of Solanum from cpDNA restriction site variation. Syst Bot 1997, 22:19-29.

45. Provan J, Powel W, Waugh R: Microsatellite analysis of relationships within cultivated potato (Solanum tuberosum). Theor Appl Genet 1996, 92:1078-1084.

46. Smulders MJM, Bredemeijer G, Rus-Kortekaas W, Arens P, Vosman $B$ : Use of short microsatellites from database sequences to generate polymorphisms among Lycopersicon esculentum cultivars and accessions of other Lycopersicon species. Theor Appl Genet 1997, 94:264-272.

47. Varshney RK, Graner A, Sorrells ME: Genic microsatellite markers: their characteristics, development and application to plant breeding and genetics. Trends Biotech 2005, 23:48-55.

48. Scott KD, Eggler P, Seaton P, Rossetto M, Ablett EM, Lee LS, Henry RJ: Analysis of SSRs derived from grape ESTs. Theor Appl Genet 2000, 100:723-726.

49. Portis E, Nervo G, Cavallanti F, Barchi L, Lanteri S: Multivariate analysis of genetic relationships between Italian pepper landraces. Crop Sci 2006, 6:2517-2525.

50. Mazzucato A, Papa R, Bitocchi E, Mosconi P, Nanni L, Negri V, Picarella ME, Siligato F, Soressi GP, Tiranti B, Veronesi F: Genetic 
diversity, structure and marker-trait associations in a collection of Italian tomato (Solanum lycopersicum L.) landraces. Theor Appl Genet 2008, 5:657-669.

5I. Altschul SF, Madden TL, Schaffer AA, Zhang J, Zhang Z, Miller W, Lipman DJ: Gapped BLAST and PSI-BLAST: a new generation of protein database search programs. Nucleic Acids Res 1997, 25:3389-3402.

52. Thompson JD, Higgins DG, Gibson TJ: Clustal W: improving the sensitivity of progressive multiple sequence alignment through sequence weighting, position-specific gap penalties and weighting matrix choice. Nucleic Acids Res 1994, 22:4673-4680.

53. Rozen S, Skaletsky HJ: Primer3 on the WWW for general users and for biologist programmers. Bioinformatics Methods and Protocols: Methods in Molecular Biology 2000:365-386 [http:// frodo.wi.mit.edu/primer3/primer3 code.html]. Humana Press, Totowa NJ

54. Doyle J], Doyle JL: Isolation of plant DNA from fresh tissue. Focus 1990, I2:13-14.

55. Jackson JA, Matthews D: Modified inter-simple sequence repeat PCR protocol for use in conjunction with the Li-Cor gene ImagIR(2) DNA analyzer. BioTechniques 2000, 28:9|4-917.

56. Botstein D, White RL, Skolnick M, Davis RW: Construction of a genetic linkage map in man using restriction fragment length polymorphism. Am J Hum Genet 1980, 32:3 I4-33I.

57. Anderson JA, Churcill GA, Autrique JE, Tanksley SD, Sorrels ME: Optimizing parental selection for genetic linkage maps. Genome 1992, 36:181-186.

58. Nei M, Li WH: Mathematical model for studying genetic variation in terms of restriction endonucleases. Proc Natl Acad Sci USA 1979, 76:5269-5273.

59. Sneath PHA, Sokal RR: Numerical taxonomy. Freeman WH, San Francisco 1973.

60. Rohlf FJ: NTSYS-pc Numerical Taxonomy and Multivariate Analysis System version 2.02 User Guide. 1998.
Publish with Biomed Central and every scientist can read your work free of charge

"BioMed Central will be the most significant development for disseminating the results of biomedical research in our lifetime. "

Sir Paul Nurse, Cancer Research UK

Your research papers will be:

- available free of charge to the entire biomedical community

- peer reviewed and published immediately upon acceptance

- cited in PubMed and archived on PubMed Central

- yours - you keep the copyright
BioMedcentral 